\title{
A Role for the Bed Nucleus of the Stria Terminalis, But Not the Amygdala, in the Effects of Corticotropin-Releasing Factor on Stress-Induced Reinstatement of Cocaine Seeking
}

\author{
Suzanne Erb and Jane Stewart \\ Center for Studies in Behavioral Neurobiology, Department of Psychology, Concordia University, Montreal, Quebec, \\ Canada H3G 1 M8
}

\begin{abstract}
We have shown that intracerebroventricular administration of the corticotropin-releasing factor (CRF) receptor antagonist D-Phe $\mathrm{CRF}_{12-41}$, blocks footshock-induced reinstatement of drug seeking in cocaine-trained rats. We now report that D-Phe acts in the bed nucleus of the stria terminalis (BNST), and not in the amygdala, to block footshock-induced reinstatement of cocaine seeking. In addition, CRF injections in the BNST, and not in the amygdala, are sufficient to reinstate cocaine seeking. Rats were trained to self-administer cocaine intravenously on a fixed ratio (FR-1) schedule of reinforcement. After 5 drug-free days, animals were returned to the self-administration chambers and given daily extinction and reinstatement test sessions. To test the effects of D-Phe $\mathrm{CRF}_{12-41}$ on stress-induced reinstatement, rats were pretreated with vehicle or D-Phe in either the BNST (10 or $50 \mathrm{ng}$ per side) or amygdala (50 or $500 \mathrm{ng}$ per
\end{abstract}

Stress has long been considered an important factor contributing to relapse to drug use in humans (Kreek and Koob, 1998) and recently, in a controlled experimental setting, was reported to induce craving for cocaine in addicts (Sinha et al., 1999). These findings are paralleled by studies in laboratory animals in which we and others have shown that brief exposure to intermittent footshock stress strongly provokes reinstatement of heroin (Shaham and Stewart, 1995), cocaine (Erb et al., 1996; Ahmed and Koob, 1997), nicotine (Buczek et al., 1999), and alcohol (Lê et al., 1998) seeking.

Recently, we demonstrated a role for the stress-related neuropeptide corticotropin-releasing factor (CRF) in the reinstatement of cocaine seeking induced by footshock stress. Intracerebroventricular administration of the CRF receptor antagonist D-Phe $\mathrm{CRF}_{12-41}$ completely blocked the footshock-induced reinstatement of cocaine seeking, both in intact animals and in adrenalectomized animals given corticosterone replacement (Erb et al., 1998) [see also Shaham et al. (1997) for studies in herointrained rats]. Such findings point to a critical role for brain CRF in the footshock-induced reinstatement of drug seeking, indepen-

Received July 8, 1999; revised Aug. 23, 1999; accepted Aug. 23, 1999.

This work was supported by grants from National Institute on Drug Abuse, Medical Research Council (Canada), and Fonds pour la Formation de Chercheurs et l'Aide à la Recherche (Quebec). S.E. was supported by graduate fellowships from Natural Sciences and Engineering Research Council (Canada) and Concordia University.

Correspondence should be addressed to Dr. Jane Stewart, 1455 de Maisonneuve Boulevard West, Montreal, Quebec, Canada H3G 1M8. E-mail: Stewart@CSBN. concordia.ca.

Copyright (ㄷ) 1999 Society for Neuroscience $\quad 0270-6474 / 99 / 190001-\bullet 05.00 / 0$ side) before being exposed to 15 min of intermittent footshock stress. To test whether injections of CRF itself could induce reinstatement, rats were given vehicle or CRF in either the BNST (100 or $300 \mathrm{ng}$ per side) or amygdala (300 ng per side) 15 min before the session. Injections of D-Phe into the BNST completely blocked footshock-induced reinstatement of cocaine seeking; injections of CRF itself in this structure induced reinstatement. Injections of these compounds into the amygdala were without effect. These findings suggest that activation of CRF receptors in the BNST, but not in the amygdala, is critical for footshock-induced reinstatement of cocaine seeking.

Key words: CRF; CRF receptor antagonist; BNST; amygdala, cocaine self-administration; reinstatement; relapse; stress

dent of the effects of CRF on the hypothalamic-pituitary-adrenal axis.

In the present experiments we examined the question of where in the brain CRF antagonists act to block stress-induced relapse. Two brain sites that contain CRF receptors (Chalmers et al., 1995) and are likely to be involved in these effects are the amygdala and the bed nucleus of the stria terminalis (BNST). Although, initially, evidence pointed to the amygdala as the primary site of action of CRF in emotional behaviors, Davis and colleagues (Lee and Davis, 1997; Gewirtz et al., 1998) have shown dissociations between the behavioral effects of CRF in the BNST and amygdala. Importantly for our purposes, they have reported a role for the BNST, and not the amygdala, in CRFinduced enhancement of the acoustic startle reflex (Lee and Davis, 1997). On the basis of these and other findings, they have argued that the actions of CRF in the BNST may be important for unconditioned emotional responses, whereas the amygdala may

This article is published in The Journal of Neuroscience, Rapid Communications Section, which publishes brief, peerreviewed papers online, not in print. Rapid Communications are posted online approximately one month earlier than they would appear if printed. They are listed in the Table of Contents of the next open issue of JNeurosci. Cite this article as: JNeurosci, 1999, 19:RC35 (1-6). The publication date is the date of posting online at www.jneurosci.org.

http://www.jneurosci.org/cgi/content/full/3589 
be preferentially involved in mediating conditioned responses (Walker and Davis, 1997; Gewirtz et al., 1998).

In light of these arguments, and because reinstatement of drug seeking can be induced by footshock stress in animals exposed to it for the first time, it seemed reasonable to hypothesize that the BNST, and not the amygdala, would play a primary role in mediating the effects of CRF antagonists in our model of stressinduced relapse. Thus in the present study, the effects of local BNST and amygdala injections of the CRF receptor antagonist D-Phe $\mathrm{CRF}_{12-41}$ on the footshock-induced reinstatement of cocaine seeking were assessed in animals trained to self-administer cocaine intravenously. In addition, we assessed the ability of intra-BNST and intra-amygdala injections of CRF, itself, to induce relapse.

\section{MATERIALS AND METHODS}

\section{Subjects}

The subjects were male Long-Evans rats (Charles River, Montreal, Quebec) (weight 325-350 g) that were housed in a colony room on a reversed light/dark schedule (lights on at 5:30 P.M. and off at 5:30 A.M.) and given free access to food and water.

\section{Surgery}

Rats were anesthetized (sodium pentobarbital, $65 \mathrm{mg} / \mathrm{kg}$, i.p.) and injected with atropine sulfate $(0.6 \mathrm{mg} / \mathrm{ml}$, s.c.; $0.2 \mathrm{ml}$ per rat $)$ and antibiotic (Penlong, Rogar/STB; $0.1 \mathrm{ml}$ per rat, i.m.). An intravenous catheter (Dow Corning) was implanted in the right jugular vein. A $3 \mathrm{~cm}$ length of SILASTIC tubing was inserted into the vein [inner diameter (ID): 0.30 $\mathrm{mm}$; outer diameter (OD): $0.64 \mathrm{~mm}$ ] and connected with heat-shrink tubing to a $9 \mathrm{~cm}$ length of SILASTIC tubing (ID: $0.51 \mathrm{~mm}$; OD: 0.94 $\mathrm{mm}$ ) that was passed subcutaneously to the top of the skull where it exited into a connector (modified 22 gauge cannula; Plastic Products). Animals were then implanted bilaterally with cannulae (22 gauge; Plastic Products) aimed $2 \mathrm{~mm}$ above either the BNST or the amygdala. Coordinates for entry of cannulae from the skull surface (midline at bregma) were taken from the atlas of Paxinos and Watson (1997). Cannulae were aimed to inject into the ventrolateral division of the BNST or the intersection of the central and basolateral nuclei of the amygdala. BNST coordinates (arms positioned at $15^{\circ}$ ) were the following: anteroposterior $(\mathrm{A} / \mathrm{P}),-0.6$; mediolateral $(\mathrm{M} / \mathrm{L}), \pm 3.7$; dorsoventral $(\mathrm{D} / \mathrm{V}),-4.6 \mathrm{~mm}$. Amygdala coordinates (arms positioned at $0^{\circ}$ ) were as follows: A/P, $-2.4 ; \mathrm{M} / \mathrm{L}, \pm 4.7 ; \mathrm{D} / \mathrm{V},-5.4 \mathrm{~mm}$. Obdurators extending $2 \mathrm{~mm}$ beyond the tip of the cannula were inserted in the cannulae. Cannulae were mounted to the skull with jeweler's screws and dental cement. Animals were allowed at least $5 \mathrm{~d}$ to recover from surgery.

\section{Apparatus}

The self-administration chambers used in the experiments were equipped with one retractable lever (Med Associates, St. Albans, VT) and one non-retractable lever, both located $9 \mathrm{~cm}$ above the floor. An infusion pump (Razel Scientific Instruments, Stamford, CT) was activated only by responses on the retractable, or "active," lever. Drug solution $(65 \mu \mathrm{l})$ was delivered over a $10 \mathrm{sec}$ period, during which time a white stimulus light above the active lever was illuminated, and additional responses were recorded but without consequence. Each self- administration chamber was fitted to deliver constant-current, intermittent, inescapable, electric footshock $(0.8 \mathrm{~mA} ; 0.5 \mathrm{sec}$ on; mean interval between shocks $40 \mathrm{sec} ; 10-70 \mathrm{sec}$ range) through a scrambler to the grid floor (Med Associates).

\section{Drugs}

Cocaine $\mathrm{HCl}$ was obtained from $\mathrm{BDH}$ Chemicals (Toronto, Ontario) and was dissolved in physiological saline. D-Phe $\mathrm{CRF}_{12-41}$ was purchased from Bachem (Torrance, CA); rat/human CRF was purchased from Sigma (Oakville, Ontario). D-Phe and CRF were dissolved in $0.5 \mu \mathrm{l}$ saline or distilled water, respectively.

\section{Procedure}

Phase 1: Training. Rats were trained to self-administer cocaine $(0.5$ $\mathrm{mg} / \mathrm{kg}$ per infusion, i.v.) on a fixed-ratio (FR)-1 schedule of reinforcement during one daily $3 \mathrm{hr}$ self-administration session. Animals were allowed a maximum of 50 infusions per session. The time of the daily training session alternated between the morning and afternoon. Training conditions were in place for 9-10 d. At the end of training, animals were left undisturbed in the colony room for $5 \mathrm{~d}$.

Phase 2: Extinction and testing. Throughout phase 2, animals were housed in the self-administration chambers and given free access to food and water, except during the daily extinction and test sessions. During extinction and testing, all of the conditions that were present during training were maintained, except that lever presses did not result in drug infusions.

Tests for reinstatement after intra-BNST or intra-amygdala injections of $D$-Phe $C R F_{12-41}$. On day 1 of phase 2, animals were given four $60 \mathrm{~min}$ self-administration sessions with $60 \mathrm{~min}$ intervening periods during which the active lever was withdrawn. On days 2 and 3 , when testing occurred, animals were given 60 min self-administration sessions with 60 min intervening periods until they made 15 or fewer responses on the active lever in $60 \mathrm{~min}$; this criterion was reached within two to three sessions. When all animals reached the baseline criterion for that day, a test for reinstatement was given.

Two tests for reinstatement (no footshock, footshock) were given on consecutive days and in a counterbalanced order. Animals were pretreated with D-Phe $\mathrm{CRF}_{12-41}$ in either the $\operatorname{BNST}(0,10$, or $50 \mathrm{ng}$ per side) or the amygdala $(0,50$, or $500 \mathrm{ng}$ per side) $30 \mathrm{~min}$ before insertion of the active lever into the chamber. In the case of the amygdala, when $50 \mathrm{ng}$ per side was found to be ineffective, the dose was raised to $500 \mathrm{ng}$ per side, previously found to be effective intracerebroventricularly. Different groups of animals were assigned to different doses of the antagonist. For the footshock tests, animals were exposed to the 15 min intermittent footshock stress immediately before lever insertion. Test sessions were 3 $\mathrm{hr}$ in duration. The footshock parameters and doses of D-Phe were based on previous work (Erb et al., 1998; Shaham et al., 1998).

Tests for reinstatement after intra-BNST or intra-amygdala injections of $C R F$. Two additional groups of animals were trained and prepared for testing as just described. On day 1 of phase 2, animals were given four 60 min extinction sessions with 30 min intervening periods during which the active lever was withdrawn. On days $2-4$, when testing occurred, animals were given $60 \mathrm{~min}$ extinction sessions with $30 \mathrm{~min}$ intervening periods until all animals responded 15 or fewer times in $60 \mathrm{~min}$ on the active lever; this criterion was reached within two to three sessions. When all animals reached the baseline criterion for that day, a test for reinstatement was given.

Animals were pretreated with CRF either into the BNST $(0,100$, or

Table 1. Responding on the active lever in training and extinction of cocaine self-administration for each treatment group

Training

Mean ( \pm SEM) number of infusions

\begin{tabular}{llll}
\cline { 3 - 3 } Injection site & Treatment & Second last day & Last day \\
\hline BNST & D-Phe (or Veh) & $39.42( \pm 2.64)$ & $38.88( \pm 2.63)$ \\
Amygdala & CRF (or Veh) & $37.60( \pm 3.77)$ & $34.60( \pm 5.04)$ \\
& D-Phe (or Veh) & $31.20( \pm 4.09)$ & $31.67( \pm 3.63)$ \\
& CRF (or Veh) & $39.30( \pm 3.43)$ & $27.10( \pm 4.30)$
\end{tabular}

Extinction (day 1)

Mean $( \pm$ SEM) number of responses (infusions + time-out responses)

\begin{tabular}{lll}
\hline Session 1 & Session 2 & Session 3 \\
\hline $55.58( \pm 5.68)$ & $25.35( \pm 3.63)$ & $14.88( \pm 2.86)$ \\
$35.80( \pm 9.31)$ & $21.80( \pm 3.73)$ & $16.9( \pm 3.14)$ \\
$28.80( \pm 5.08)$ & $27.40( \pm 12.44)$ & $14.40( \pm 2.79)$ \\
$56.7( \pm 12.06)$ & $13.88( \pm 3.22)$ & $2.25( \pm 1.83)$
\end{tabular}

Veh, Vehicle. 
$300 \mathrm{ng}$ ) or into the amygdala ( 0 or $300 \mathrm{ng}$ per side) $15 \mathrm{~min}$ before insertion of the active lever in the self-administration chamber. No footshock was administered in this experiment. All animals were tested at each dose of CRF on consecutive days and in a counterbalanced order.

\section{RESULTS}

Table 1 shows the mean $( \pm$ SEM) number of infusions of 0.5 $\mathrm{mg} / \mathrm{kg}$ cocaine made in the $3 \mathrm{hr}$ sessions on the last $2 \mathrm{~d}$ of training and the mean $( \pm$ SEM) number of responses (infusions + timeout responses) made during the first three $1 \mathrm{hr}$ extinction sessions on day 1 of phase 2 for animals in each treatment condition.

\section{Intra-BNST injection of D-Phe $\mathbf{C R F}_{\mathbf{1 2 - 4 1}}$}

Data from 24 animals, 8 per group, were used in the analyses for the tests for reinstatement. One animal that had improperly placed cannulae was excluded from the analyses. This animal, whose cannulae lay just posterior to the BNST, was given $50 \mathrm{ng}$ D-Phe and showed robust footshock-induced reinstatement (110 responses on the active lever in $3 \mathrm{hr}$ ). See Figure $1 A$ for a diagram showing the distribution of injector tips of animals used in the analyses with BNST cannula implants. It can be seen from Figure $2 A$ that pretreatment with 10 and $50 \mathrm{ng}$ of the CRF antagonist D-Phe completely blocked the footshock-induced reinstatement of cocaine seeking in these animals. A mixed-factor ANOVA for responding on the active lever revealed a significant interaction between dose and test condition $\left(F_{(2,21)}=7.25, p<0.01\right)$. A subsequent one-factor ANOVA conducted for the footshock condition revealed a significant effect of dose $\left(F_{(2,21)}=9.62, p<\right.$ 0.01 ). See Figure $2 A$ for reliable post hoc comparisons (Fisher's LSD, $p<0.05$ ). A mixed-factor ANOVA conducted for responses on the inactive lever revealed no significant effects.

\section{Intra-BNST injections of CRF}

Data from 10 animals were used in the analyses for the tests for reinstatement; no animals were excluded. The distribution of injector tips in the BNST is shown in Figure $1 A$. It can be seen from Figure $2 B$ that the $300 \mathrm{ng}$ dose of CRF induced reinstatement of cocaine seeking; $100 \mathrm{ng}$ was not effective. A repeatedmeasures ANOVA for number of responses on the active lever revealed a significant effect of dose $\left(F_{(2,18)}=18.17, p<0.001\right)$. A similar analysis of responding on the inactive lever was also significant $\left(F_{(2,18)}=5.89, p<0.03\right)$. Therefore, difference scores (responses on active lever minus responses on inactive lever) were calculated for each subject, and these scores were entered into a repeated-measures ANOVA. This analysis revealed a significant effect of dose $\left(F_{(2,18)}=5.13, p<0.03\right)$. See Figure $2 B$ for reliable post hoc comparisons (Fisher's LSD, $p<0.05$ ).

\section{Intra-amygdala injections of D-Phe $\mathbf{C R F}_{\mathbf{1 2 - 4 1}}$}

Data from 15 animals, 5 per group, were used in the analyses for the tests for reinstatement. Eleven animals, four from the $50 \mathrm{ng}$ and seven from the $500 \mathrm{ng}$ group, were excluded from the analyses because of misplacement of one of the cannulae bilaterally. (Removal of the data for these animals made no difference to the outcome, inasmuch as no effects of amygdala injections were found.) Because there was a relatively wide distribution of injector tips throughout the central and basolateral nuclei (Fig. 1B), and because of the known differential effects of CRF on cell firing in these two regions (Rainnie et al., 1992), separate analyses were conducted for the animals with placements in basolateral and central nuclei. There was no significant difference between the effects in the two areas after either the D-Phe CRF or CRF injections (see below).

Figure $3 A$ shows that neither the 50 nor 500 ng dose of D-Phe
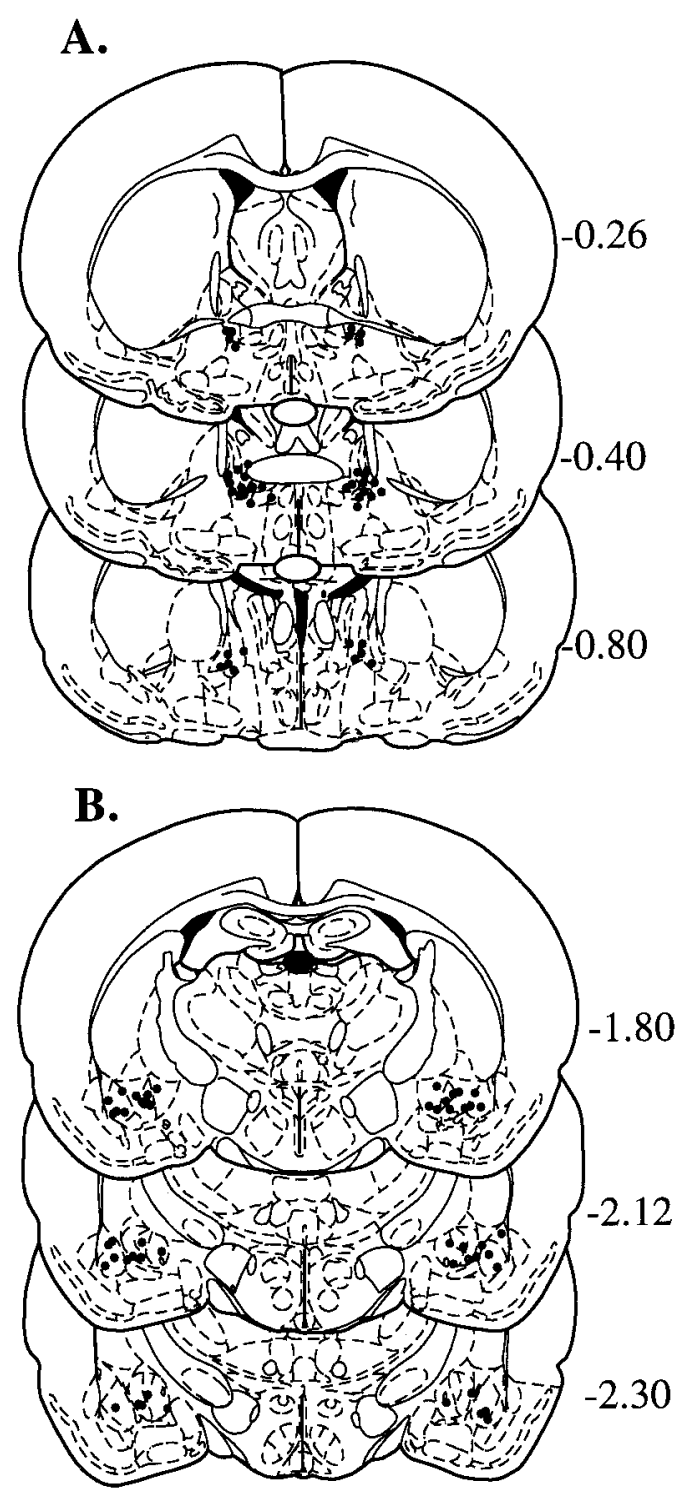

Figure 1. $A$, Placement of injector tips for animals with BNST cannula implants for D-Phe $\mathrm{CRF}_{12-41}$ and CRF; $B$, placement of injector tips for animals with amygdala cannula implants for D-Phe $C F_{12-41}$ and CRF. Values at right represent millimeters from bregma. Drawings are adapted from Paxinos and Watson (1997).

$\mathrm{CRF}_{12-41}$ interfered with footshock-induced reinstatement of cocaine seeking. A mixed-factor ANOVA for responding on the active lever revealed only a significant effect of test condition $\left(F_{(1,12)}=9.08, p<0.03\right)$; regardless of dose, animals responded more under the footshock than the no footshock test condition. A similar analysis conducted for responses on the inactive lever revealed no significant effects.

\section{Intra-amygdala injections of CRF}

Data from 10 animals were used in the analyses for the tests for reinstatement. One animal that had improperly placed cannulae was excluded from the analyses. Another animal that was found to have extremely enlarged ventricles and an atrophied hippocampus was also excluded from the analyses. See Figure $1 B$ for a diagram showing the distribution of injector tips of animals used in the analyses with amygdala cannula implants.

The number of responses made on the active lever in the $3 \mathrm{hr}$ 
A. D-PHE IN BNST

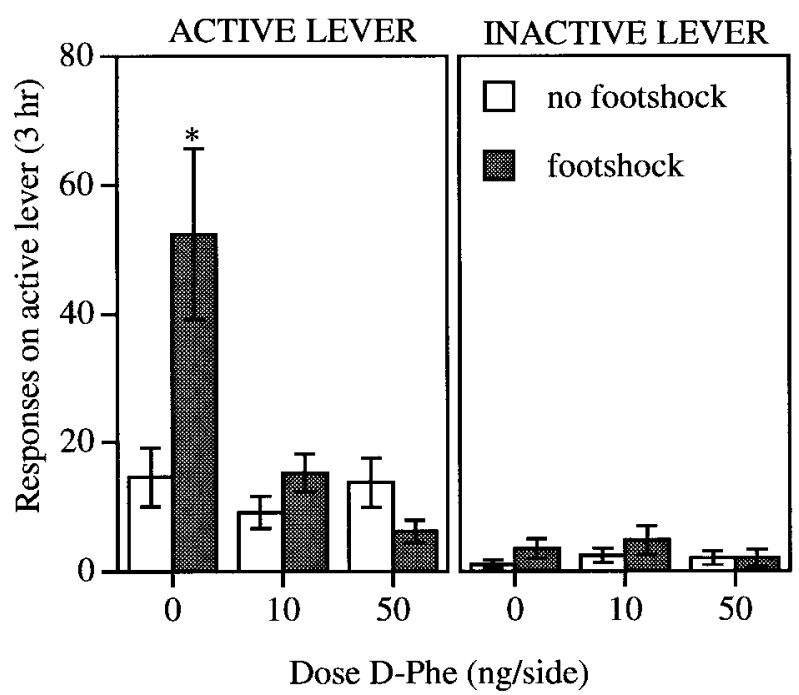

B. CRF IN BNST (no footshock)

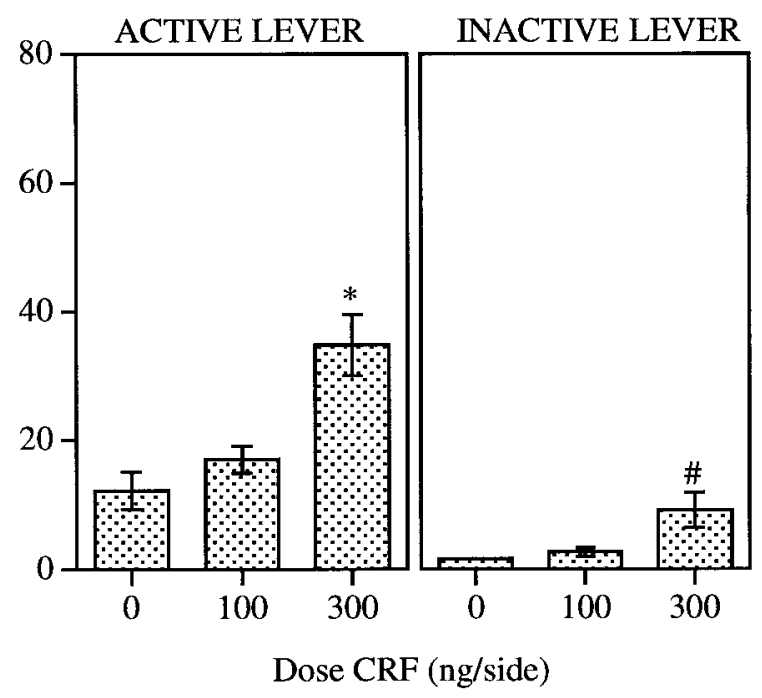

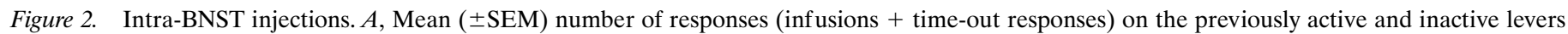

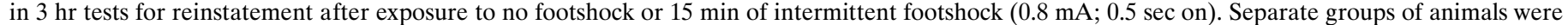

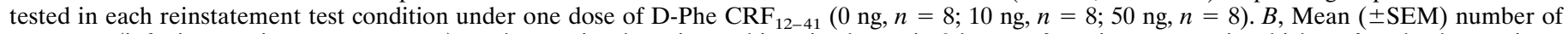

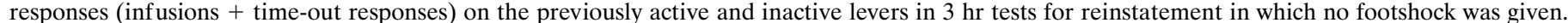

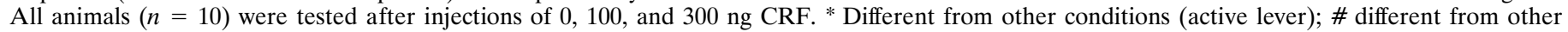
conditions (inactive lever).

\section{A. D-PHE IN AMYGDALA}

Figure 3. Intra-amygdala injections. $A$, Mean $( \pm$ SEM) number of responses (infusions + time-out responses) on the previously active and inactive levers in $3 \mathrm{hr}$ tests for reinstatement after exposure to no footshock or $15 \mathrm{~min}$ of intermittent footshock $(0.5 \mathrm{~mA} ; 0.5 \mathrm{sec}$ on). Separate groups of animals were tested in each reinstatement test condition under one dose of D-Phe $\mathrm{CRF}_{12-41}(0 \mathrm{ng}, n=5 ; 50 \mathrm{ng}, n=$ 5 ; $500 \mathrm{ng}, n=5)$. $B$, Mean ( \pm SEM) number of responses (infusions + time-out responses) on the previously active and inactive levers in $3 \mathrm{hr}$ tests for reinstatement in which no footshock was given. All animals $(n=10)$ were tested after injections of 0 and $300 \mathrm{ng}$ CRF.

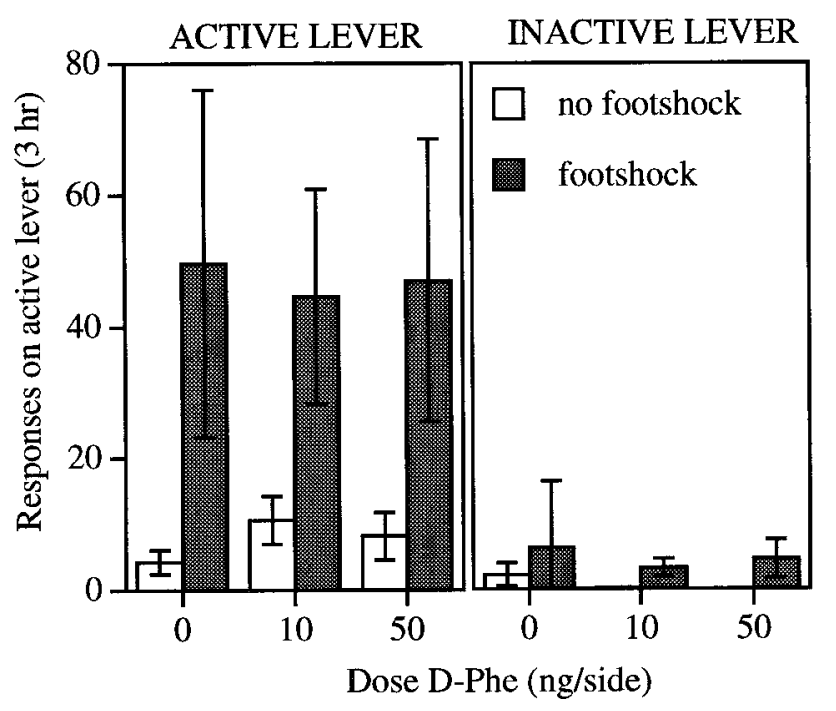

\section{B. CRF IN AMYGDALA (no footshock)}

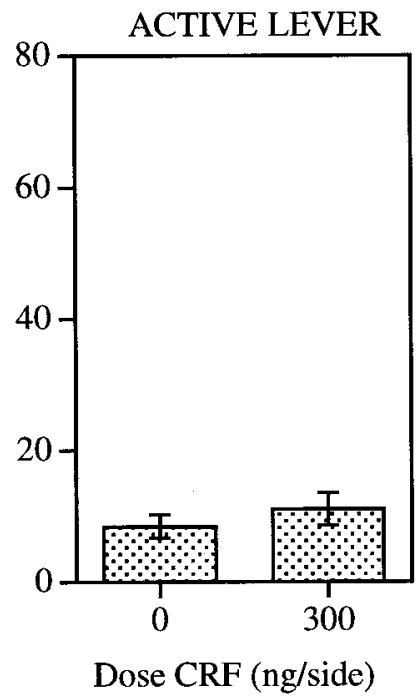

tests for reinstatement after injections of CRF ( 0 and $300 \mathrm{ng}$ ) is shown in Figure $3 B$. The same dose of CRF that reinstated cocaine seeking when injected into the BNST had no effect when injected into the amygdala. A paired-samples $t$ test for number of responses on the active lever after 0 and $300 \mathrm{ng}$ CRF was not significant $\left(t_{(9)}=0.89 ; p=0.40\right)$.

\section{DISCUSSION}

Two principal findings emerge from the present experiments. First, intra-BNST administration of a CRF receptor antagonist at a dose 10 times lower than that effective when given intracerebroventricularly abolishes footshock-induced reinstatement of co- caine seeking in the rat. In contrast, intra-amygdala injections of doses as high as those that are effective when given intracerebroventricularly are completely without effect. Second, local administration of CRF into the BNST, but not the amygdala, induces reinstatement of cocaine seeking, mimicking, at least in part, the effects of footshock on relapse.

The findings obtained in the present study are consistent with those of Davis and colleagues (Lee and Davis, 1997), suggesting that the BNST, and not the amygdala, is responsible for the unconditioned emotional changes induced by CRF. Lee and Davis (1997) showed, for example, that lesions of the BNST and not the amygdala interfered with the effects of CRF administered 
intracerebroventricularly, and that intra-BNST injections of CRF enhanced startle responses. Furthermore, our findings support the view that the BNST is preferentially involved in mediating behavioral responses to unconditioned stress (Walker and Davis, 1997; Gewirtz et al., 1998); in the present experiments, neither the footshock stressor nor the CRF injections had been paired previously with the self-administration environment and were, as such, unconditioned stressors.

Injections of CRF and its receptor antagonist into the BNST could mimic or block the effects of CRF released locally from cells intrinsic to this structure (Veinante et al., 1997). It must be kept in mind, however, that although injections of CRF and D-Phe $\mathrm{CRF}_{12-41}$ into the amygdala neither induced reinstatement nor interfered with footshock-induced reinstatement, the amygdala cannot be ruled out as a component of the circuitry mediating the effect of stress. A CRF-containing projection from the amygdala to the BNST has been identified (Sakanaka et al., 1986), and stress-induced activation of this pathway could be responsible, in part, for the increases in CRF found in the BNST after exposure to stress (Lee and Davis, 1997).

Although in the present experiments intra-BNST injections of both the CRF antagonist and CRF were effective, and consistent with the findings of others, one must be concerned about diff usion of injected compounds to other structures, such as the septum, substantia innominata, and preoptic area, that lie close to the BNST and contain moderate to high levels of CRF receptors (Chalmers et al., 1995). We are reassured, therefore, by the fact that injections of D-Phe $\mathrm{CRF}_{12-41}$ made through cannulae placed improperly just posterior to the BNST were ineffective in blocking the effects of footshock on relapse.

As mentioned previously, CRF could be released in the BNST by cells intrinsic to that structure or via a projection from the amygdala. We have reason to think, however, that the unconditioned stress activation of CRF in our experiments may involve noradrenergic (NE) input to the BNST. We have found recently that the $\alpha$-2 agonist clonidine, which acts to inhibit NE activity, effectively blocks stress-induced reinstatement of both cocaine and heroin seeking (S. Erb, P. K. Hitchcott, H. Rajabi, D. Mueller, Y. Shaham, J. Stewart, unpublished observations; Y. Shaham, D. Highfield, J. Delfs, S. Leung, J. Stewart, unpublished observations), and we have evidence that this effect of clonidine may be mediated by the ventral NE bundle (Y. Shaham, D. Highfield, J. Delfs, S. Leung, J. Stewart, unpublished observations), which is known to provide a massive projection to the BNST (Aston-Jones et al., 1995; Terenzi and Ingram, 1995). Thus we speculate that stress-induced activation of NE neurons of the ventral bundle, whose terminals lie in close proximity to (Hornby and Piekut, 1989) and in fact synapse with dendrites of CRF-containing cells of the ventral BNST (Phelix et al., 1994), may be responsible for $\mathrm{CRF}$ release in that region. To explore this interaction between $\mathrm{NE}$ and $\mathrm{CRF}$ in the BNST, we used in vivo microdialysis to measure NE release in the BNST in response to footshock after intracerebroventricular injections of D-Phe $\mathrm{CRF}_{12-41}$. These injections, previously found to block footshock-induced reinstatement (Erb et al., 1998), did not interfere with footshock-induced NE release (our unpublished data). We suggest, therefore, that the effects of the CRF antagonist and CRF in the BNST occur subsequent to the actions of NE in this region. At present one can only speculate about how CRF acting in the BNST serves to initiate the behaviors involved in relapse.

It is interesting in this context, however, to consider the fact that animals with a history of drug taking appear to be highly sensitive to footshock stress-induced relapse. We and others have shown in several studies, using procedures similar to those described here, that animals trained to self-administer food, sucrose pellets, or sucrose solutions show little evidence of stress-induced reinstatement of these behaviors (Ahmed and Koob, 1997; Buczek et al., 1999). We suggest that after a period of drug exposure, the NE system innervating the BNST may show a heightened response to stress that could conceivably act to enhance CRF release in the region. We are currently exploring this possibility.

Finally, although D-Phe $\mathrm{CRF}_{12-41}$ is a nonselective CRF receptor antagonist (Menzaghi et al., 1994), it is important to note that CRF-1 and CRF-2 receptors are differentially distributed in the brain (Chalmers et al., 1995) and are functionally dissociable (e.g., Heinrichs et al., 1997; Radulovic et al., 1999). Although both receptors are present in the BNST, in the lateral division of the BNST there are more CRF-1 than CRF-2 receptors, and it is there that they are most abundant (Chalmers et al., 1995). It would appear, therefore, that CRF-1 receptors are especially important for mediating the effects of footshock on relapse. Consistent with this possibility, we have shown previously that systemic injections of the nonpeptide CRF-1 receptor antagonist CP-154, 526 block footshock-induced reinstatement of cocaine and heroin seeking (Shaham et al., 1998) as effectively as intracerebroventricular infusions of peptide CRF antagonists (Erb et al., 1998; Shaham et al., 1998).

In summary, we have demonstrated in the present study a role for the BNST in the effects of CRF and its receptor antagonists on the reinstatement of cocaine seeking. Furthermore, we have shown that CRF receptors in the amygdala, a structure anatomically and functionally related to the BNST, appear not to play a role in the stress-induced reinstatement of cocaine seeking. Finally, we propose a possible interaction between NE and CRF systems in the BNST in the mediation of the effects of footshock stress on relapse.

\section{REFERENCES}

Ahmed SH, Koob GF (1997) Cocaine- but not food- seeking behavior is reinstated by stress after extinction. Psychopharmacology 132:289-295.

Aston-Jones G, Shipley MT, Grzanna R (1995) The locus coeruleus, A5 and A7 noradrenergic cell groups. In: The rat nervous system (Paxinos G, ed), pp 183-213. San Diego: Academic.

Buczek Y, Wang A, Stewart J, Shaham Y (1999) Stress reinstates nicotine seeking, but not sucrose solution seeking rats. Psychopharmacology 144:183-188.

Chalmers D, Lovenberg T, De Souza E (1995) Localization of novel corticotropin-releasing factor receptor $\left(\mathrm{CRF}_{2}\right)$ mRNA expression to specific subcortical nuclei in rat brain: comparison with $\mathrm{CRF}_{1}$ receptor mRNA expression. J Neurosci 15:6340-6350.

Erb S, Shaham Y, Stewart J (1996) Stress reinstates cocaine-seeking behavior after prolonged extinction and a drug-free period. Psychopharmacology 128:408-412.

Erb S, Shaham Y, Stewart J (1998) The role of corticotropin-releasing factor and corticosterone in stress- and cocaine-induced relapse to cocaine seeking in rats. J Neurosci 18:5529-5536.

Gewirtz J, McNish K, Davis M (1998) Lesions of the bed nucleus of the stria terminalis block sensitization of the acoustic startle reflex produced by repeated stress, but not fear-potentiated startle. Prog Neuropsychopharmacol Biol Psychiatry 22:625-648.

Heinrichs S, Lapsansky J, Lovenberg T, De Souza E, Chalmers D (1997) Corticotropin-releasing factor CRF1, but not CRF2, receptors mediate anxiogenic-like behavior. Regul Pept 71:15-21.

Hornby P, Piekut D (1989) Opiocortin and catecholamine input to CRFimmunoreactive neurons in rat forebrain. Peptides 10:1139-1146.

Kreek MJ, Koob GF (1998) Drug dependence: stress and dysregulation of brain reward systems. Drug Alcohol Depend 51:23-47.

Lê AD, Quan B, Juzystch W, Fletcher PJ, Joharchi N, Shaham Y (1998) 
Reinstatement of alcohol-seeking by priming injections of alcohol and exposure to stress in rats. Psychopharmacology 135:169-174.

Lee Y, Davis M (1997) Role of the hippocampus, the bed nucleus of the stria terminalis and the amygdala in the excitatory effect of corticotropin-releasing hormone on the acoustic startle reflex. J Neurosci 17:6434-6440.

Menzaghi F, Howard RL, Heinrichs SC, Vale W, Rivier J, Koob GF (1994) Characterization of a novel and potent corticotropin-releasing factor antagonist in rats. J Pharmacol Exp Ther 269:564-572.

Paxinos G, Watson C (1997) The rat brain in stereotaxic coordinates. New York: Academic.

Phelix CF, Liposits Z, Paull WK (1994) Catecholamine-CRF synaptic interaction in a septal bed nucleus: afferents of neurons in the bed nucleus of the stria terminalis. Brain Res Bull 33:109-119.

Radulovic J, Rühmann A, Liepold T, Spiess J (1999) Modulation of learning and anxiety by corticotropin-releasing factor (CRF) and stress: differential roles of CRF receptors 1 and 2. J Neurosci 19:5016-5025.

Rainnie, DG, Fernhout, BJ, Shinnick-Gallagher, P (1992) Differential actions of corticotropin releasing factor on basolateral and central amygdaloid neurones, in vitro. J Pharmacol Exp Ther 263::846-858.

Sakanaka M, Shibasaki T, Lederis K (1986) Distribution and efferent projections of corticotropin-releasing factor-like immunoreactivity in the rat amygdaloid complex. Brain Res 382:213-238.

Shaham Y, Stewart J (1995) Stress reinstates heroin-seeking in drug-free animals: an effect mimicking heroin, not withdrawal. Psychopharmacology 119:334-341.

Shaham Y, Funk D, Erb S, Brown T, Walker C-D, Stewart J (1997) Corticotropin-releasing factor, but not corticosterone, is involved in stress-induced relapse to heroin-seeking in rats. J Neurosci 17:2605-2614.

Shaham Y, Erb S, Leung S, Buczek Y, Stewart J (1998) CP-154,526, a selective, nonpeptide antagonist of the corticotropin-releasing factor type 1 receptor attenuates stress-induced relapse to drug seeking in cocaine- and heroin-trained rats. Psychopharmacology 137:184-190.

Sinha R, Catapano D, O’Malley S (1999) Stress-induced craving and stress response in cocaine dependent individuals. Psychopharmacology 142:343-351.

Terenzi M, Ingram C (1995) A combined immunocytochemical and retrograde tracing study of noradrenergic connections between the caudal medulla and bed nuclei of the stria terminalis. Brain Res 672:289-297.

Veinante P, Stoeckel M-E, Freund-Mercier M-J (1997) GABA- and peptide-immunoreactivity co-localize in the rat central extended amygdala. NeuroReport 8:2985-2989.

Walker D, Davis M (1997) Double dissociation between the involvement of the bed nucleus of the stria terminalis and the central nucleus of the amygdala in startle increases produced by conditioned versus unconditioned fear. J Neurosci 17:9375-9383. 